Отримано: 28 лютого 2019 р.

Прорецензовано: 6 березня 2019 р.

Прийнято до друку: 11 березня 2019 p.

e-mail: karanevych.m@gmail.com

oksana.kutsa.tnpu@gmail.com

DOI: 10.25264/2519-2558-2019-5(73)-29-31

PhD in Philological Sciences, Associate Professor, Ternopil Volodymyr Hnatiuk National Pedagogical University Oksana Kutsa,

PhD in Pedagogical Sciences, Associate Professor, Ternopil Volodymyr Hnatiuk National Pedagogical University
Mariana Karanevych, Oksana Kutsa. Reproduction of the pragmatic potential in fiction translation. Наукові записки Начіонального університету "Острозька академія». серія «Філологія». Острог: Вид-во НаУОА, 2019. Вип. 5(73), березень. С. 29-31.

\title{
REPRODUCTION OF THE PRAGMATIC POTENTIAL IN FICTION TRANSLATION
}

The paper examines reproduction of the pragmatic potential of fiction in translation. The relevance of the study is determined by great interest of linguistic science to pragmatic aspects of translation. The objective of the research is to reveal the ways of achievement of adequate English-Ukrainian fiction translation. From the outcome of our investigation we can conclude that equipollent pragmatic effect of an original literary work and its translation is possible in case of pragmatic competence of a translator. In fact, pragmatically adequate translation entails understanding of a message, rendering of emotional impact of a source text in a target text, intended influence on a concrete recipient in a definite communicative situation. At the same time, fulfillment of "extra task" leads to pragmatic deformation in translation. To reproduce the pragmatic potential of belles-letters successfully, a translator fulfills the functions of a loupe, a transformer, and a filter. Pragmatic focus influences introduction of pragmatically motivated lexical and grammatical transformations, taking into consideration lingual and cultural stereotypes of a target audience. Such changes result in the translated message that is functionally equipollent to the original. The results of the investigation can be effectively used to compare and contrast features specific to different literary genres from the pragmatic perspective.

Key words: pragmatic potential, fiction translation, pragmatically motivated transformations, pragmatic competence.

Караневич Мар'яна Ігорівна,

кандидат філологічних наук, доцент, Тернопільський національний педагогічний університет імені Володимира Гнатюка Куца Оксана Ігорівна,

кандидат педагогічних наук, доцент, Тернопільський начіональний педагогічний університет імені Володимира Гнатюка

\section{ВІДТВОРЕННЯ ПРАГМАТИЧНОГО ПОТЕНЦІАЛУ ХУДОЖНЬОГО ТВОРУ В ПЕРЕКЛАДІ}

У статті розглянуто відтворення прагматичного потениіалу в художньому перекладі. Основна увага авторів зосереджена на способах забезпечення адекватного англо-українського перекладу художніх творів. Встановлено, щзо досягнення рівноиінного прагматичного ефекту оригіналу та перекладу за допомогою прагматично зумовлених трансформаиій можслве лите за умови прагматичної компетениї перекладача, який керується прагматичним фокусом, а також мовними та культурними стереотипами иільової аудиторії вторинного тексту. Водночас, прагматичні деформації неминуче призводять до втрат. Результати проведеного дослідження можуть бути використані для порівняння способів прагматичної адаптачії художніх творів різних жанрів.

Ключові слова: прагматичний потенціал, художній переклад, прагматично зумовлена трансформація, прагматична компетенція.

Every year the number of translated literature on the Ukrainian book market becomes bigger. This situation is the result of the state policy aiming to facilitate the spread of the Ukrainian language in all spheres of life. Fiction translation opens for the Ukrainian readers a window to the world of foreign authors and cultures.

In the course of time scholars have investigated different aspects of fiction translation: lexical [16], cultural [17], and stylistic [15]. However, there is still a need for discussion of pragmatics of literary translation. With this in mind we tried to analyze the ways of reproduction of the pragmatic potential of the English text in the Ukrainian translation.

Pragmatic adequacy of translation depends on the pragmatic competence of a translator. It enables him/her to understand the meaning of the utterance in a particular context and use lingual resources to achieve certain aims effectively $[11$, c. $10 ; 12$, c. $10 ; 13$, c. $159 ; 14$, c. 69 ]. Linguist V. Komissarov singled out four types of pragmatic adaptation depending on the translator's intention: 1) ensuring of adequate understanding of a message by means of addition [4, c. 137]: He went to Brown [24, с. 14]. - Він поӥхав до університету Брауна [19, с. 6]; Oxford, New Mexico [25, с. 132] - <..> у тому Оксфорді, що в штаті Нью-Мексико [21, с. 132]. Sometimes, to avoid ambiguity, a translator needs to explicate the information that is implicitly expressed in the original [10, c. 49]: I want to point out that maybe he's saving himself [24, c. 97]...-Я збиралася зауважити, що, може, він себе береже до илюбу [19, с. 80]. But one should bear in mind that extensive usage of explanations, footnotes and translator's commentaries makes comprehension of the text complicated, 'shatters' its composition [9, c. 261].; 2) rendering of emotional impact of a source text in a target text. Representatives of different lingual communities may have different associations with some lexical items [4, c. 139-140]. Thus, pragmatic competence of a translator presupposes language competence as well as intercultural competence, as illustrated in the following example: It was a few days before the Fourth of July, and a grey, scrawny Italian child was setting torpedoes in a row along the railroad track [25, с. 29]. - Наближався День незалежнності, і сірі, замурзані діти італійських іммігрантів прилаштовували петарди вздовж залізничної колії [21, с. 29].; 3) ensuring of intended influence on a concrete recipient in a definite communicative situation [4, c. 142]. This type of pragmatic adaptation is often used for translation of names of literary works, films, programmes in order to make them sound more usual and natural for the target audience [4, c. 143]. To achieve equipollent communicative effect a translator may use other lexical means and grammatical forms than those used in the original: For example, R. Bradbury's work "Night Call” [23] is translated into Ukrainian as «Розмова за пільговим тарифом» [18]. Literal translation of 
titles may be confusing for the Ukrainian readers, as is illustrated in the following example: "The Bed and Breakfast Star" [26] «Зірка з ліжкка та сніданку» [20]. We cannot be sure of the fact that having read the title of J. Wilson's novel the average Ukrainian teenager can guess what the story is about. The service system of B\&B hotels is well-known only to travellers.; 4) fulfillment of "extra task" [4, c. 143]. Ideology, censorship, some special will of a translation consumer can influence the target text, which leads to distortion of its meaning, change of its communicative effect. Luckily, we did not reveal the fulfillment of "extra task" in the analyzed English-Ukrainian translations.

To render the pragmatics of an original adequately, it is necessary to follow the algorithm: 1) to reveal pragmatic meanings of the source text; 2) to determine their interrelations; 3 ) to discover the role of each pragmatic element in pragmatics of the whole text [6, c. 231]. In the process of fiction translation a translator fulfills the following functions: 1) a filter, because s/he transfers the information that is understandable for the target audience; 2) a loupe, because s/he amplifies details that may remain unnoticed by the recipients of a translated text, but are essential for understanding of this literary work; 3) a transformer, because s/he renders elements of an original that cannot be adequately understood by the readers of a target text who use another linguo-cultural dimension [5, c. 83]. But in the process of transformation one should always take into consideration a 'translation invariant'. This term is used to indicate the element of a source text that is vitally important for rendering of an intended communicative effect [2, c. 105]. When analyzing the pragmatic aspect of translation, scholars also use the term 'pragmatic focus'. It denotes the act of selection of information to be transferred by means of a target language, the relevance of which is determined within the framework of some pragmatic intention. Communication and interaction efficiency is considered to be the criterion of a pragmatic focus [3, c. 125]. It influences introduction of changes into the translated text: 1) addition of explanations and commentaries: I graduated from New Haven in $1915<\ldots>[25$, c. 5]. - 1915 року я завершив вищу освіту в Нью-Гейвені [22, с. 5]. Translator M. Pinchevskyi added the following explanation to the geographical name: "Yale University is located in New-Haven". However, translator A. Pekhnyk suggested another way of

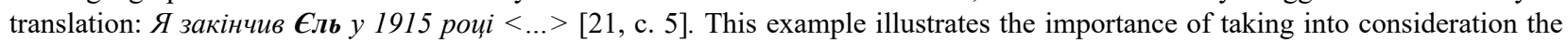
context (communication about education) and background knowledge of the target audience (for an average Ukrainian the above mentioned geographical name is not directly associated with a world-famous educational institution).; 2) omission or substitution of incomprehensible and irrelevant information for the recipient of a target text. This transformation is mainly used when a translator deals with metric unit conversion or phraseology: fifty feet [25, с. 59] - два десятки кроків [21, с. 59]; as drunk as a monkey [25, c. 83] - n'яна як иіп [21, с. 83]. However, in our opinion, the translation of the following extract is inadequate: Glasses bigger than finger-bowls [25, с. 52]. - < .. > бокалах, більших від невеликої салатниці [21, с. 52] / <..> в келихах завбільшки з добрячу полоскальницю [22, с. 59]. We suggest another way of rendering of the highlighted lexical item: < ... бокалах, більших від чаш для обмивання рук.; 3) rendering of contaminated speech. Usually, there are no problems with reproduction of stammering: I'm p-paralyzed with happiness [25, с. 12]. - Мене пар-р-ралізувало від щзастя [21, с. 12]. But the examples below illustrate pragmatically inadequate translation, because a translator ignored phonetic peculiarities of the speech of a drunk person: Here, deares. Take 'em downstairs give 'em back to whoever they belong to. Tell 'em all Daisy's change' her mine. Say 'Daisy's change' her mine!' [25, с. 83] - Віднеси ие вниз і поверни тому, кому воно належить. Скажи їм, що Дейзі передумала. Так і скажи: “Дейзі передумала»! [21, с. 83] and grammatical peculiarities of the speech of an uneducated character: There was two cars, one comin', one goin', see [25, с. 152]? - Там було дві машини. Одна їхала туди, друга - сюди [21, с. 152]. Thus, some relevant information provided by the writer remains unnoticed for the Ukrainian reader.; 4) changes introduced because of the necessity of adherence to genre and style norms that exist in the target language [8, c. 164-167].

When a translator gets to work, s/he needs to make their choice: 1) to identify himself/herself with the author of an original message and his/her readers with the readers of the source text. In this case it is necessary to use pragmatically motivated transformations to achieve equipollent communicative effect. Thus, the pragmatic meaning of the original remains unchanged while semantic and syntactic dimensions may be completely or partly modified. One of the most important features of pragmatically motivated transformations is that changes of separate elements of the source message are introduced to save the meaning of the whole. Such phenomenon can be observed in translation of idioms, realia and different clichés [1, c. 395-397]; 2) to focus on a target audience, trying to create the communicative effect that is presupposed in a new communicative situation. When a translator deliberately changes the communicative effect that was intended by the author of a source text, pragmatic deformations are used [1, c. 394-395]. But according to M. Rebenko, when it comes to pragmatic potential of an original, deformations inevitably lead to losses [7, c. 148].

Based on the above, we can conclude that fiction translation requires the usage of 'pragmatically motivated transformations'. This term in our work is used to denote lexical and semantic or grammatical changes, caused by dominant pragmatic intention of a translator to render the meaning and emotional colouring of a source text to the fullest extent, taking into consideration lingual and cultural stereotypes of a target audience. Such changes result in the translated message that is functionally equipollent to the original. They are used to adapt the sense and form of an original for the target audience, because of differences in background knowledge of readers. To provide adequate translation a translator needs to take into consideration the following factors: culture-specific lexical items in the system of artistic values of a literary work, literary canons of a target language, the pragmatic focus of a message.

\section{Література:}

1. Гарбовский Н. К. Теория перевода. Москва: Издательство Московского университета, 2004. 544 с.

2. Гусаров Д. А. От прагматики высказывания к прагматике перевода. Армия и общество. 2008. Вип. 4. С. 102-108.

3. Кальченко Г. Прагматична структура екологічного дискурсу. Проблеми семантики, прагматики та когнітивної лінгвістики. 2006. Вип. 10. С. 122-127.

4. Комиссаров В. Н. Современное переводоведение. Москва: ЭТС, 2004. 424 с.

5. Нуриев В. А. Адекватность перевода как лингвистическая проблема. Вестник Воронежского государственного университеma. 2003. Вип. 1. С. $80-87$.

6. Олійник Т. С. Переклад поетичних текстів: прагматичний аспект. Гуманітарний вісник. 2007. Вип. 1. С. $227-232$.

7. Ребенко М. Ю. Місце прийому деформації в теорії адаптивного перекладу. Вісник Луганського начіонального університету імені Тараса Шевченка. 2010. Вип. 13 (200). С. 143-150.

8. Сдобников В. В., Петрова О. В. Теория перевода. Москва: АСТ: Восток-Запад, 2007. 448 с.

9. Сегол Р. Прагматика перекладу як основа міжмовної комунікації. Журналістика. Лінгвістика. Дидактика. 2010. С. $258-262$. 
10. Чередниченко А.И. Языковая вариативность и перевод. Теорія та практика перекладу. 1980. Вип. 4. С. $46-53$.

11. Barron A. Acquisition in Interlanguage Pragmatics: Learning How to Do Things with Words in a Study Abroad Context. Philadelphia: John Benjamins Publishing, 2001. 398 p.

12. Carston R. Thoughts and Utterances: the Pragmatics of Explicit Communication. Oxford: Blackwell Publishers Ltd., 2002.418 p.

13. Cutting J. Pragmatics and Discourse. London, New York: Routledge, 2002. 187 p.

14. Dooly M. Semantics and Pragmatics of English: Teaching English as a Foreign Language. Barcelona: University Autonoma de Barcelona, 2006. $83 \mathrm{p}$.

15. Ghazal H.S. Literary Translation from a Stylistic Perspective. Studies in English Language Teaching. 2015. Vol. 3 (2). P. $124-145$.

16. Giaber J.M. Implications of Lexical Choices in Translating Novels as Literary Texts. trans-com. 2015. Vol. 8 (2). P. $415-445$.

17. Khrais S.M. Literary Translation and Cultural Challenges: JhumpaLahiri's The Namesake. International Journal of Comparative Literature \& Translation Studies. 2017. Vol. 5 (1). P. 80-86.

\section{Список джерел ілюстративного матеріалу:}

18. Бредбері Р. Розмова за пільговим тарифом / пер. $з$ англ. Б. Салика. Пригоди, подорожі, фантастика-83.1983. С. 208-218.

19. Бушнелл К. Щоденник Керрі / пер. 3 англ. К. Плугатир. Київ: KM Publishing, 2011. 352 c.

20. Вілсон Дж. Зірка з ліжка та сніданку / пер. з англ. В. Чернишенка. Тернопіль: Навчальна книга - Богдан, 2011. 224 с.

21. Фіцджеральд Ф.С. Великий Гетсбі / пер. з англ. А. Пехника. Київ: Знання, 2014. 198 с.

22. Фіцджеральд Ф.С. Великий Гетсбі / пер. з англ. М. Пінчевського. Київ: ТОВ «Компанія «ВЕЛМАЙТ»», 2014. 224 с.

23. Bradbury R. Night Call Collect. URL: https://ghostradio.wordpress.com/2012/06/07/audio-bradbury-13-night-call-collect/ (Дата звернення: 10.02.2019).

24. Bushnell C. The Carrie Diaries. New York: Balzer + Bray, 2011. 410 p.

25. Fitzgerald F.S. The Great Gatsby. Kyiv: Znannia, 2013. 198 p.

26. Wilson J. The Bed and Breakfast Star. URL: https://books.google.com.ua/books?id=xrTWneEFHvMC\&pg=PP2\&lpg=PP2\&dq=W ilson+J.+The+Bed+and+Breakfast+Star\&source (Дата звернення: 10.02. 2019). 